\title{
Deoxyribonucleic Acid Homology Relationships Among Species of the Genus Bifidobacterium
}

\author{
V. SCARDOVI, L. D. TROVATELLI, G. ZANI, F. CROCIANI, and D. MATTEUZZI
}

Istitu to di Microbiologia Agraria, Università di Bologna, Bologne, Italy

\begin{abstract}
Genetic relatedness among 179 strains representing 13 named species and several unnamed taxa of the genus Bifidobacterium from three main habitats, i.e., (i) feces of man, (ii) feces of various other animals, and (iii) the bovine rumen, was assessed by means of deoxyribonucleic acid (DNA)-DNA hybridization by using a filter-paper technique in competition experiments. Assignment of these strains to the genus Bifidobacterium was based on the production of lactic and acetic acids as chief products from glucose, lack of gas production, fructose-6-phosphate phosphoketolase activity, and on morphology. About 180 DNA competitors were tested with 23 reference systems. Several genetically distinct groups were recognized. Little or no DNA homology was demonstrated between some of the groups, suggesting large evolutionary divergence in this genus. B. infantis, B. liberorum, and B. lactentis form one of these groups; the ecological significance of this relatedness was discussed. The DNA of the following pairs are homologous: (i) $B$. breve and $B$. parvulorum, (ii) B. thermophilum and B. ruminale, and (iii) $B$. pseudolongum and $B$. globosum. Within a number of strains assigned to $B$. adolescentis, many of which were isolated from waste waters, a large genetic heterogeneity was demonstrated: in addition to B. adolescentis, at least three unrelated groups were recognized and are provisionally referred to as "dentium," "catenulatum," and "angulatum." Since these groups are not related genetically to any species of the genus and are phenotypically distinct, they may represent new species. The validity of the species $B$. bifidum, $B$. longum, and $B$. suis was confirmed at the genetic level.
\end{abstract}

The bifid bacteria are anaerobic, nonmotile, gram-positive, non-sporeforming, rodlike organisms which are often irregularly shaped, clubshaped, or rudimentarily branched in "Y" or similar forms. Glucose is fermented through the fructose-6-phosphate shunt leading to acetic and lactic acids as chief end products in the approximate ratio $1.5: 1.0(7,39,43)$. All known strains of bifidobacteria are catalase negative and do not reduce nitrate. The taxonomy of the bifid bacteria, which at present are assigned to the single genus Bifidobacterium, has always been a vexing problem ( 16 , 33,35 ), and the question of the relationships of the bifidobacteria with the actinomycetes, lactobacilli, and corynebacteria, particularly with respect to comparative cell wall chemistry (16) and general biochemistry (33), has further complicated the problem.

Although only a single species was originally included by Orla-Jensen (30) in the genus Bifidobacterium, subsequent work $(26,27,34$, $36,40,41)$ has brought to 16 the number of named species in this genus. These species (including their subspecies and biotypes), together with their distinctive fermentation patterns and other characters, are listed in Table 1. The species have been differentiated mainly on the basis of fermentative characters, and therefore it is no wonder that there are many taxonomic uncertainties. B. bifidum has a very recognizable fermentation pattern. However, the distinction between the ribosefermenting species not fermenting arabinose and xylose, i.e., B. infantis, B. breve, and $B$. parvulorum, is not easy. Also, B. liberorum and $B$. lactentis are not easily differentiated from each other. Their common morphologies and sources of isolation add to the difficulty. In addition, rumen and animal strains in the 
TABLE 1. Differential characters of the species of the genus Bifidobacterium ${ }^{a}$

A Isolated from feces and vaginas of humans

B. bifidum (Tissier) Prévot biotype $a$

B. infantis Reuter b $b$

B. infantis biotype $b$

B. breve Reuter biotype

B. breve biotype $b$
B. breve bioty $c$ c

(4) B. parvulorum Reuter biotype $a$

B. parvulorum biotype $b$

(6) B. lactentis Reuter

(7) B. adolescentis Reuter biotype $\begin{array}{ll}\text { B. adolescentis } & \text { biotype } b \\ \text { B. adolescentis } & \text { biotype }\end{array}$

B. adolescentis biotype $d$

B. longum Reuter subsp. longum Reuter biotype

gum biotype $b$

B Isolated from feces of various animals and from bovine rumen B. longum Reuter subsp. animalis Mitsuoka biotype $a$

B. longum subsp. animalis biotype $b$

(9) B. pseudolongum Mitsuoka bioty pe

$B$. pseudolongum biotype $b$.

. pseudolongum biotyped

(10) B. suis Matteuzzi et al. . . .

(12) B. thermophilum Mitsuoka biotype

B. thermophilum biotype $b$

B. thermophilum biotype $c$

(13) B. globosum Scardovi tet al .

B. globosum (mannitol fementi........

C Isolated from the intestines of honey bees

(14) B. asteroides Scardovi et al.

(15) B. indicum Scardovi et al.
(16) B. coryneforme Scardovi et

\begin{tabular}{|c|c|c|c|c|c|c|c|c|c|c|c|c|c|c|}
\hline 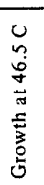 & 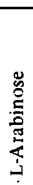 & 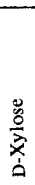 & 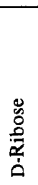 & 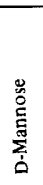 & 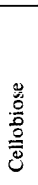 & 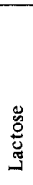 & 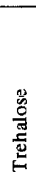 & 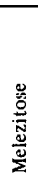 & $\begin{array}{l}\text { 预 } \\
\text { is }\end{array}$ & 喅 & $\begin{array}{l}\overline{0} \\
\stackrel{0}{\tilde{E}} \\
\text { 吾 }\end{array}$ & $\begin{array}{l}\overline{0} \\
\stackrel{0}{0} \\
\text { 응 }\end{array}$ & 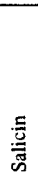 & 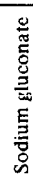 \\
\hline - & 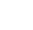 & 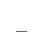 & _ & - & \pm & + & - & - & - & - & - & $\ldots$ & - & 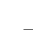 \\
\hline - & 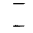 & $\overline{-}$ & $\bar{z}$ & - & \pm & + & - & - & - & - & - & - & - & - \\
\hline - & - & - & + & + & + & $t$ & + & - & - & + & - & $\ldots$ & + & - \\
\hline - & - & - & + & $\stackrel{+}{+}$ & $\overline{+}$ & + & - & $z$ & $\begin{array}{l}+ \\
d^{2}\end{array}$ & \pm & + & + & + & - \\
\hline $\bar{z}$ & $\overline{-}$ & $\overline{-}$ & + & + & + & + & + & + & d & - & + & + & + & - \\
\hline- & - & - & + & + & + & + & - & + & $\mathrm{d}$ & $\pm 1-$ & + & + & + & - \\
\hline- & - & - & + & + & + & + & \pm & $\bar{t}$ & + & $\bar{x}$ & - & - & + & 7 \\
\hline$=$ & - & + & $\begin{array}{l}+ \\
+\end{array}$ & $\begin{array}{l}+ \\
+\end{array}$ & $\begin{array}{l}+ \\
+\end{array}$ & + & $\stackrel{ \pm}{+}$ & + & $\begin{array}{l}+ \\
\pm\end{array}$ & $\begin{array}{l} \pm \\
\pm\end{array}$ & - & I & + & 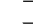 \\
\hline- & - & + & $+*$ & + & \pm & + & + & - & $+*$ & + & + & - & - & - \\
\hline - & + & + & + & $+*$ & + & + & $+*$ & $+*$ & + & + & + & + & + & + \\
\hline- & + & + & + & - & + & + & + & $+*$ & + & + & + & - & + & + \\
\hline$\overline{-}$ & $\begin{array}{l}+ \\
+\end{array}$ & $\begin{array}{l}+ \\
+\end{array}$ & $\stackrel{+}{t}$ & \pm & + & $\stackrel{+}{+}$ & $\begin{array}{l}+ \\
+*\end{array}$ & $+*$ & $\begin{array}{l}\text { d } \\
+\end{array}$ & + & \pm & + & $\stackrel{+}{+}$ & $\stackrel{+}{+}$ \\
\hline - & + & + & + & \pm & - & & $+*$ & + & & $+*$ & 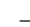 & _. & - & 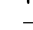 \\
\hline - & + & + & + & + & - & + & + & + & \pm & $+*$ & - & - & - & - \\
\hline - & + & + & + & - & - & + & - & - & \pm & - & - & - & \pm & - \\
\hline - & + & + & + & + & - & + & - & - & \pm & - & - & - & \pm & - \\
\hline- & + & + & + & - & \pm & + & - & - & + & - & - & - & \pm & - \\
\hline- & $\stackrel{+}{+}$ & $\stackrel{+}{+}$ & $\stackrel{+}{+}$ & $\begin{array}{l}+* \\
+*\end{array}$ & ${ }^{+}+$ & $\stackrel{+}{+}$ & - & $\bar{t}$ & $\begin{array}{l}+ \\
+\end{array}$ & $=$ & 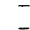 & $=$ & $+*$ & - \\
\hline - & + & + & + & $+*$ & $+*$ & - & - & - & + & - & - & - & + & - \\
\hline - & + & + & $\mathrm{nt}$ & + & - & + & - & - & - & - & - & - & - & - \\
\hline - & - & - & - & - & - & - & - & - & + & - & - & - & $\mathrm{nt}$ & - \\
\hline+ & - & - & - & - & d & - & d & - & + & - & - & - & \pm & - \\
\hline$T$ & - & - & - & - & + & + & - & \pm & $\begin{array}{l}+ \\
+\end{array}$ & $\overline{+}$ & 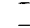 & I & $\begin{array}{l}+ \\
+\end{array}$ & 7 \\
\hline+ & - & - & _ & - & + & + & + & + & + & + & $\ldots$ & - & + & - \\
\hline 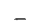 & - & - & + & - & - & + & - & - & + & - & - & - & $n t$ & - \\
\hline- & + & + & + & - & $\mathrm{d}$ & + & - & - & + & - & + & - & $n t$ & - \\
\hline - & + & + & $\mathrm{nt}$ & - & + & - & - & - & - & nt & - & - & + & + \\
\hline- & - & - & $\mathrm{nt}$ & - & + & - & - & - & - & $\mathrm{nt}$ & - & - & + & + \\
\hline- & + & + & $\mathrm{nt}$ & - & + & - & - & - & - & $\mathrm{nt}$ & - & - & + & + \\
\hline
\end{tabular}

${ }^{a}$ Data are taken from Reuter (36), Mitsuoka (27), Scardovi and Trovatelli (40), Scardovi et al. (41), and Matteuzzi et al. (26).

Symbols: $+*$, delayed reaction; \pm , delayed and weak fermentation; d, different reaction in different strains (27); reactions concerning a few strains in some of the taxa were overlooked; nt, not tested. Additional characters: the results with other polysaccharides or glucosides (27) are similar to those with starch and
salicin, respectively. $B$. bifidum biotype $a$ (from adults) slowly ferments sucrose and melibiose; $B$. bifidum biotype $b$ (from infants) does not ferment sucrose but vigorously ferments melibiose (27); both biotypes do not ferment maltose or raffinose. All bifidobacteria ferment (for exceptions, see above): glucose, galactose,
fructose (somewhat slow in $B$. pseudolongum), sucrose, maltose, and melibiose. Never fermented are rhamnose and glycerol. For other compounds tested, see Mitsuoka (27) and Reuter (36). Inositol is fermented only by $B$. infantis biotype $b$ and $B$. liberorum; inositol is fermented slowly by $B$. lactentis (27). 
species $B$. ruminale and $B$. thermophilum or $B$. adolescentis biotype $d$ and $B$. longum have nearly identical fermentation patterns. The species from the intestines of bees can be distinguished mainly on morphological grounds. Further separation of the species into subspecies and biotypes would only add to the confusion.

Additional work on phenotypic characters, e.g., nutritional requirements, behavior toward oxygen (8), distribution of some enzymes like aldolase or dehydrogenases, and lipid composition (9), might be of value in the speciation of the genus Bifidobacterium. However, cell wall analysis (16) has already demonstrated the heterogeneity of the genus Bifidobacterium since the various murein types (sequence of amino acids in the interpeptide bridge) correlate well with species or groups of species. Some irregularities in the results obtained by Kandler (16), i.e., different murein types found in $B$. adolescentis, reflect the genetic heterogeneity of the strains analyzed.

Three types of electrophoretic behavior of fructose-6-phosphate phosphoketolase were found in strains of Bifidobacterium (38); the $R_{F}$ of the enzyme is not correlated with the names of the species but rather with their main habitats: feces or body cavities of man, feces of other animals, and intestines of bees. This suggests different evolutionary trends in the various ecological niches.

Scardovi et al. (42) and Crociani et al. (3) reported experimental data concerning the genetic relatedness among some proposed species of Bifidobacterium from the rumen of cattle and the intestines of honey bees. Genetic relatedness was assessed by means of deoxyribonucleic acid (DNA)-DNA hybridization in competition experiments. This approach offers a direct measure of the similarity or homology of the polynucleotide sequences in DNA molecules and therefore of the genetic relatedness of many groups of bacteria. The results clearly indicated that the genus Bifidobacterium is not as genetically homogenous as could be argued from the narrow range of DNA base composition [ 60 to $65 \%$ guanine plus cytosine (GC)] and from overall phenotypic similarity.

The present study excludes strains from bees, the genetic relatedness of these strains already having been investigated by Scardovi et al. (42). This investigation is here expanded to determine the genetic relatedness of representative strains of all other named species (and certain unnamed strains) of Bifidobacterium to contribute to a better understanding of the taxonomy of this genus.

\section{MATERIALS AND METHODS}

Bacterial strains. The strains employed in this study, together with their sources, are listed in Table 2. All strains were repeatedly examined for adherence to species or subspecies characteristics prior to use, especially those received from foreign collections (see Table 1). Regardless of their source, strains were considered to be members of Bifidobacterium if glucose was fermented and yielded acetic and lactic acids in the approximate ratio of 1.5:1.0 without gas and if fructose-6-phosphate phosphoketolase activity was present in cell-free extracts. These criteria were strictly applied to strains from unusual habitats, like waste waters, where morphological forms only superficially resembling bifids could easily be overlooked.

DNA preparations. Cells for DNA extraction were grown on Trypticase-Phytone-glucose medium of the following composition: Trypticase (BBL), $0.5 \mathrm{~g}$; Phytone (BBL), $0.2 \mathrm{~g}$; glucose, $1.5 \mathrm{~g}$; yeast extract (Difco), $0.1 \mathrm{~g}$; cysteine-hydrochloride, $0.05 \mathrm{~g}$; $\mathrm{K}_{2} \mathrm{HPO}_{4}, 0.2 \mathrm{~g} ; \mathrm{MgCl}_{2} \cdot 6 \mathrm{H}_{2} \mathrm{O}, 0.05 \mathrm{~g} ; \mathrm{ZnSO}_{4} \cdot 7 \mathrm{H}_{2} \mathrm{O}$, $0.025 \mathrm{~g} ; \mathrm{CaCl}_{2}, 0.015 \mathrm{~g}$ and traces of $\mathrm{FeCl}_{3} \cdot 7 \mathrm{H}_{2} \mathrm{O}$; distilled water, $100 \mathrm{ml}$. The substrate, distributed in the amount of $900 \mathrm{ml}$ into conical flasks $(1,000 \mathrm{ml})$, was sterilized at $110 \mathrm{C}$ for $30 \mathrm{~min}$, gassed with carbon dioxide through a porous glass disc for approximately 2 min (final $p \mathrm{H} 6.2$ to 6.4 ), and then inoculated with about $100 \mathrm{ml}$ of culture. The cells were grown to the stationary phase and then centrifuged, washed with saline, and suspended in $0.15 \mathrm{M} \mathrm{NaCl}$ and $0.1 \mathrm{M}$ ethylendiaminetetraacetic acid $(p H$ 8.0). Lysozyme followed by sodium lauryl sulfate was used to lyse the cells; this technique and the subsequent purification of DNA from cell lysates were described by Marmur (23). Labeled DNA was obtained from cells grown in the presence of $50 \mu \mathrm{Ci}$ each of uracil-2-14C and adenine$8-14 C$ per liter. All DNA preparations were stored at $4 \mathrm{C}$ in $0.1 \mathrm{X} \mathrm{SSC}(0.015 \mathrm{M} \mathrm{NaCl}$ and $0.0015 \mathrm{M}$ sodium citrate) with chloroform as preservative.

DNA immobilization. Native DNA (about $80 \mu \mathrm{g} / \mathrm{ml})$ was alkali-denaturated $(0.1 \mathrm{M} \mathrm{KOH}$ for $15 \mathrm{~min}$ ) in $0.1 \mathrm{X} \mathrm{SSC}$ at room temperature, diluted $1: 10$ with cold $6 \mathrm{XSSC}$, and fixed by slow filtration in the cold through $15-\mathrm{cm}$ membrane filters (Sartorium Membranfilter SM 11306 or Selectron filter BA 85/1; Schleicher \& Schuell Co., Dassel), presoaked in $6 \mathrm{X}$ SSC for $12 \mathrm{hr}$. The filters were washed with $200 \mathrm{ml}$ of 6X SSC, dried overnight in air, and cut with a paper punch into small filters $10.5 \mathrm{~mm}$ in diameter; the small filters were then dried in a vacuum oven at $80 \mathrm{C}$ for $2 \mathrm{hr}$ and stored at $4 \mathrm{C}$. The amount of DNA fixed on each small filter ranged from 30 to $50 \mu \mathrm{g}$.

DNA hybridization. We used the single-point competition reaction and the conditions employed by Johnson and Ordal (15) for ensuring satisfactory binding and minimizing nonspecific annealing. The filters with the immobilized DNA (reference DNA) were preincubated at $69 \mathrm{C}$ in a vessel containing the preincubation mixture of Denhardt (6) made up with 2X SSC. After 4 to $6 \mathrm{hr}$ of preincubation, the filters were removed and excess water was blotted off. The filters were then placed singly in 4-ml screw-cap vials which contained $0.25 \mathrm{ml}$ of Denhardt's mixture containing 1.0 to $2.0 \mu \mathrm{g}$ of denatured, labeled DNA and 
TABLE 2. List of strains

\begin{tabular}{llc}
\hline Organism & Culture received \\
from
\end{tabular}

Bifidobacterium bifidum (Tissier) Orla-Jensen

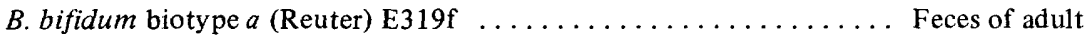

B. bifidum bioty pe $b$ (Reuter) S28a (ATCC 15696) . . . . . . . . Feces of infant Lactobacillus bifidus subsp. pennsylvanicus Gyorgy (ATCC 11683) . . . Feces of infant B. bifidum biotype? B884; B888; B953 .............. Human vagina Bifidobacterium infantis Reuter S12 (ATCC 15697) [type strain (37)] . . Feces of infant Bifidobacterium parvulorum Reuter

$B$. parvulorum biotype $a$ S50 (ATCC 15698) [type strain (37)] . . . . Feces of infant

B. parvulorum bioty pe $b \mathrm{~S} 17 \mathrm{c}$ (ATCC 15699) .............. Feces of infant Bifidobacterium liberorum Reuter S76e (ATCC 15702) [type strain (37)] Feces of infant Bifidobacterium lactentis Reuter 659 (ATCC 25962) [ty pe strain (37)] . Feces of infant

\section{Bifidobacterium breve Reuter}

$B$. breve biotype $a$

S1 (ATCC 15700) [type strain (37)] . . . . . . . . . . . . Feces of infant

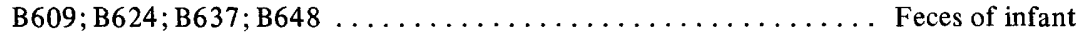
B860; B912;B943 ....................... Human vagina

B. breve biotype $b$

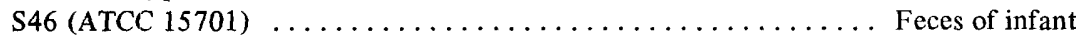

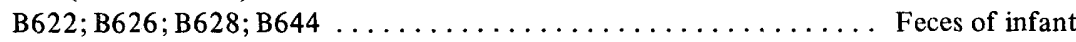

B828; B862;B941 ...................... Human vagina

B. breve biotype? Cellobiose negative

B627; B632; B633; B641; B644 ..................Feces of infant

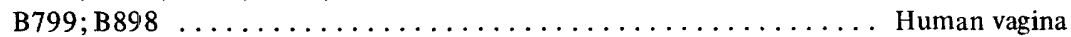

Unassigned strains: $\mathrm{B} 721 ; \mathrm{B} 723 \quad \ldots \ldots \ldots \ldots \ldots \ldots \ldots \ldots \ldots$ Human vagina

Bifidobacterium longum Reuter

B. longum biotype $a$ E194b (ATCC 15707) [type strain (37)] . . . . . Feces of adult

B. longum biotype $b \mathrm{~S} 3(\mathrm{ATCC} 15708) \ldots \ldots \ldots \ldots \ldots \ldots \ldots$ Feces of infant

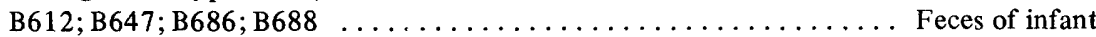

B800; B821; B923; B929 ... . . . . . . . . . . . . . Human vagina

B. longum R.euter subsp. animalis Mitsuoka

biotype $a$ R 101-8 (ATCC 25527) [type strain (27)] . . . . . . . Feces of rat

biotype $b \mathrm{C} 10-45 \ldots \ldots \ldots \ldots \ldots \ldots \ldots$ Feces of calf

Bifidobacterium globosum Scardovi et al.

RU224 (ATCC 25865) [type strain (41)] . . . . . . . . . . . Rumen of cattle

RU230 (ATCC 25864); RU240; RU255; RU256 ............ Rumen of cattle

RU257; RU323; RU324; RU457 . . . . . . . . . . . . Rumen of cattle

Bifidobacterium pseudolongum Mitsuoka

B. pseudolongum biotype $a$ PNC-2-9G (ATCC 25526) [type strain (27)] Feces of pig

B. pseudolongum biotype $b 28 \mathrm{~T} \ldots \ldots \ldots \ldots \ldots \ldots \ldots \ldots \ldots \ldots \ldots \ldots$ Feces of chicken

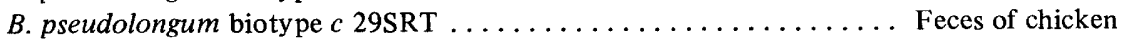

B. pseudolongum biotype $d \mathrm{Mo} 2-10 \ldots \ldots \ldots \ldots \ldots \ldots$ Feces of mouse

Bifidobacterium thermophilum Mitsuoka

B. thermophilum bioty pe $a$ P2-91 (ATCC 25525) [type strain (27)] . . Feces of pig

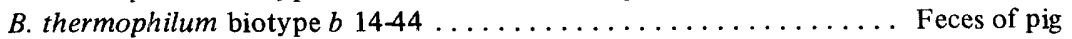

B. thermophilum biotype $c \mathrm{P} 16-6 \ldots \ldots \ldots \ldots \ldots \ldots \ldots$ Feces of pig

B. thermophilum bioty pe $d$ Nissin $\ldots \ldots \ldots \ldots \ldots \ldots \ldots \ldots$ Feces of pig

Bifidobacterium ruminale Scardovi et al.

RU326 (ATCC 25866); RU263; RU268; RU279 . . . . . . . . . . . Rumen of cattle RU290; RU356; RU381; RU417; RU431; RU445 (ATCC 25867) . . . . Rumen of cattle R variants RU276; RU348; RU354 . . . . . . . . . . . . . Rumen of cattle
G. Reuter

G. Reuter

Our collection

G. Reuter

G. Reuter

G. Reuter

G. Reuter

G. Reuter (isolated by Dehnert)

G. Reuter

Our collection

Our collection

G. Reuter

Our collection

Our collection

Our collection

Our collection

Our collection

G. Reuter

G. Reuter

Our collection

Our collection

T. Mitsuoka

T. Mitsuoka

Our collection

Our collection

Our collection

T. Mitsuoka

T. Mitsuoka

T. Mitsuoka

T. Mitsuoka

T. Mitsuoka

T. Mitsuoka

T. Mitsuoka

T. Mitsuoka

Our collection

Our collection

Our collection 
TABLE 2.-(Continued)

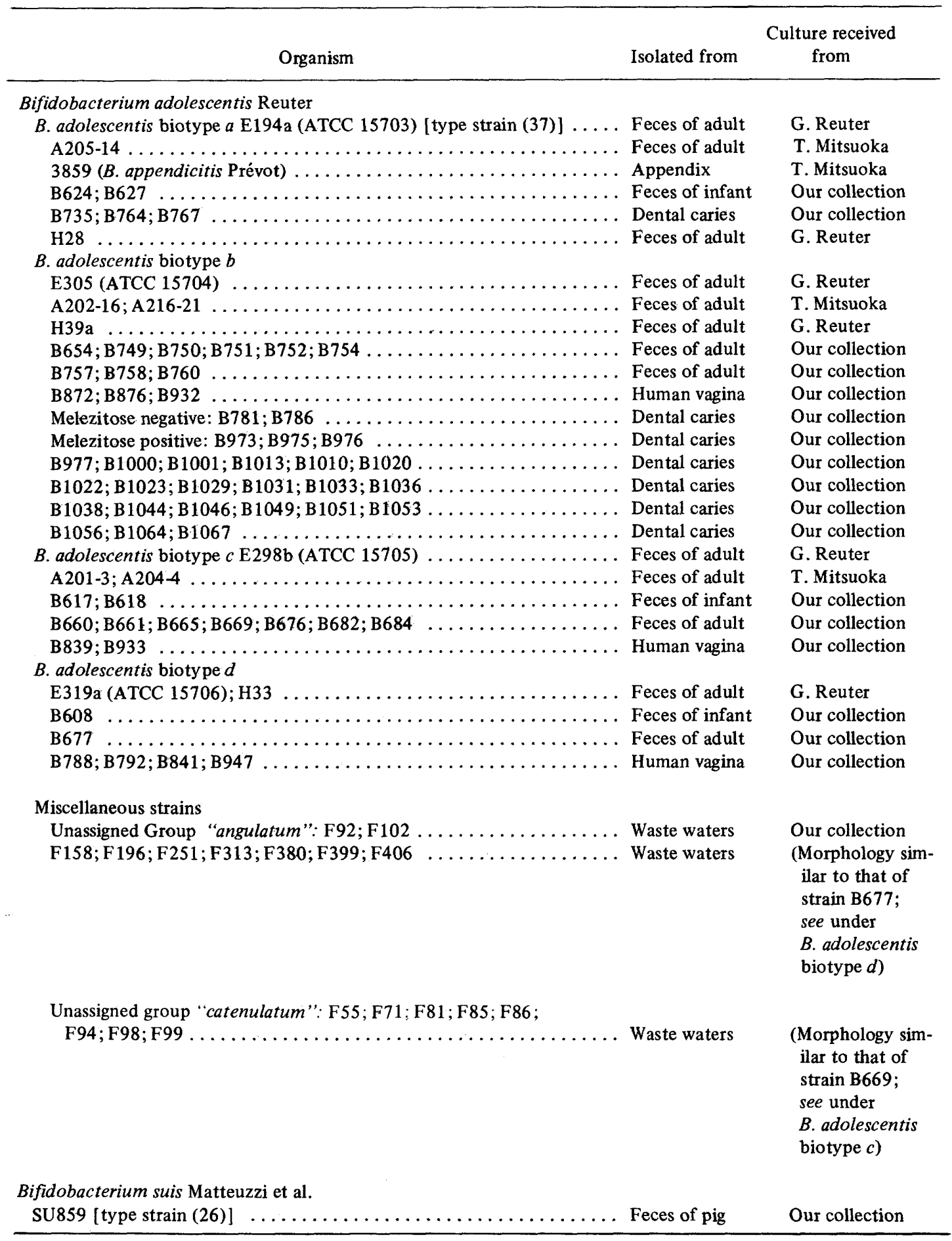


$150 \mu \mathrm{g}$ of denatured competitor DNA in 2X SSC. These DNA preparations, in 0.1X SSC, had been sheared by passage through a French pressure cell at about $10,000 \mathrm{psi}(21)$ and prior to use were denaturated by heating in a boiling-water bath for $10 \mathrm{~min}$. The amount of competitor DNA was sufficient to reach the necessary saturation plateau for single-point competition test. The vials were gently shaken by means of a wrist-action shaker for $12 \mathrm{hr}$ at the temperature of $69 \mathrm{C}, 25 \mathrm{C}$ below the melting temperature $\left(\mathrm{T}_{\mathrm{m}}\right)$ as determined in $1 \mathrm{X} \mathrm{SSC}$. After incubation, the filters were washed on both sides with $2 \mathrm{X} \mathrm{SSC}$ at $69 \mathrm{C}$, dried under an infrared lamp, and counted with a liquid-scintillation counter. Homology or similarity values were calculated in per cent of binding with respect to the depression measured with the homologous system, i.e., with the equation (counts without competitor DNA - counts with heterologous DNA)/ (counts without competitor DNA - counts with homologous DNA) $\times 100$.

DNA base composition. The per cent GC (moles of guanine plus cytosine) was determined by using the thermal denaturation method of Marmur and Doty (24). Curves of optical density variations and temperature were recorded with a Tm analyzer (Beckman Instruments Inc.).

\section{RESULTS}

Homology relationships among type strains of the species of Bifidobacterium. Species from human feces. Outlines of the DNA homology among the type strains of the species isolated from human feces and proposed by Reuter (36, 37) are reported in Table 3.

$B$. breve and $B$. parvulorum are undoubtedly more strongly related to each other than to any other species studied in this work. The two strains of $B$. parvulorum, $\mathrm{S} 50$ and $\mathrm{S} 17 \mathrm{c}$, have 88 and $94 \%$ homology to strain $S 1$ (B. breve) as reference organism, and in reciprocal reaction the strains $\mathrm{S} 1$ and $\mathrm{S} 46$ (B. breve) display 98 and $106 \%$ homology with strain S50 (B. parvulorum). Strain $\mathrm{S} 12$ of $B$. infantis displayed lower, but still considerable, levels of similarity to the references $B$. breve (strain $\mathrm{S} 1$ ) and $B$. parvulorum strain S50: 50 and $45 \%$, respectively. Similar levels of similarity to $B$. breve and $B$. parvulorum were found with DNA competitors from B. liberorum and B. lactentis. The DNA from other species has little or no homology with that of $B$. breve.

The strains of the species $B$. infantis, $B$. liberorum, and $B$. lactentis form what appears to be a well-defined homology group: their relative homology values, measured with each of the strains used as reference, fall within a range of 70 to $100 \%$ (see the third and the last two columns of Table 3 ).

The two strains of B. bifidum do not share any appreciable polynucleotide sequences with other species but are completely related to each other; the same is true for the strains of the biotypes of $B$. adolescentis, although some discrepancies were observed in the reciprocal competition experiments. The two proposed biotypes of $B$. longum can be sharply distinguished from the other species by virtue of their similarity values but they can also be distinguished from each other. They seem to be somewhat less related to each other than the biotypes within other species of Bifidobacterium. The other species which seem to be

TABLE 3. Deoxyribonucleic acid homology values among strains (including type strains) of Bifidobacterium species isolated from man $^{a}$

\begin{tabular}{|c|c|c|c|c|c|c|c|c|c|c|c|c|c|c|}
\hline & \multirow[t]{2}{*}{ Competitor strains } & \multicolumn{13}{|c|}{ Reference strains } \\
\hline & & S1 & S46 & $\mathbf{S} 12$ & S50 & S17c & E319f & E194a & E298b & E319a & E194b & S3 & $\mathrm{S} 76 \mathrm{e}$ & 659 \\
\hline S1 & B. breve biotype $a \ldots \ldots \ldots$ & 100 & 84 & 45 & 106 & & 27 & & 4 & & & 43 & 34 & 25 \\
\hline S46 & B. breve biotype $b \ldots \ldots \ldots$ & 86 & 100 & 39 & 98 & & 25 & & 5 & & & & & \\
\hline S12 & B. infantis $\ldots \ldots \ldots \ldots$ & 50 & & 100 & 45 & & 42 & & & & & 60 & 77 & 92 \\
\hline S50 & B. parvulorum biotype $a \ldots \ldots$ & 88 & & 45 & 100 & 84 & & & 0 & & & & 31 & 57 \\
\hline $\mathrm{S} 17 \mathrm{c}$ & B. parvulorum biotype $b \ldots$ & 94 & & 45 & 86 & 100 & & & 0 & & & & & \\
\hline E319f & B. bifidum biotype $a \ldots \ldots$ & 10 & & 20 & 13 & & 100 & & & & & 2 & & \\
\hline S28a & B. bifidum biotype $b \ldots \ldots$ & 20 & & 28 & & & 100 & & 3 & & & & & \\
\hline E194a & B. adolescentis biotype $a \ldots \ldots$ & 10 & & 10 & & & & 100 & 63 & 60 & & & & \\
\hline E305 & B. adolescentis biotype $b \ldots \ldots$ & 5 & & 5 & & & & 95 & 70 & 80 & & 20 & & \\
\hline $\mathrm{E} 298 \mathrm{~b}$ & B. adolescentis biotype $c \ldots \ldots$ & 6 & & 10 & 30 & & 13 & 96 & 100 & 82 & 30 & & & \\
\hline $\mathrm{E} 319 \mathrm{a}$ & B. adolescentis biotype $d \ldots$ & 5 & & 5 & & & & 87 & 90 & 100 & & & & \\
\hline E194b & B. longum biotype $a \ldots \ldots$ & 12 & & 15 & 34 & & 15 & & & 0 & 100 & 70 & 13 & 43 \\
\hline S3 & B. longum biotype $b \ldots \ldots$ & & & & & & & & & 0 & 75 & 100 & & \\
\hline $\mathrm{S} 76 \mathrm{e}$ & B. liberorum $\ldots \ldots \ldots \ldots$ & 42 & & 77 & 45 & 24 & & & & 0 & & 52 & 100 & 92 \\
\hline 659 & B. lactentis $\ldots \ldots \ldots \ldots \ldots$ & 17 & & 70 & 40 & 22 & & & & 0 & & 46 & 77 & 100 \\
\hline
\end{tabular}

${ }^{a}$ Homology or similarity value is calculated in percentage of binding depression in respect to depression of the homologous system $(=100)$. 
related to $B$. longum with little more than $50 \%$ homology are $B$. liberorum, $B$. lactentis, and $B$. infantis.

Species from animals. The DNA homology values of the type strains of the species found in the feces of various animals and in the rumen of cattle relative to six reference organisms are reported in Table 4. Three of the four biotypes of $B$. thermophilum (i.e., $a, b, c$ ) behave as expected and are $100 \%$ homologous with the type strain of $B$. thermophilum, P2-91, as reference, whereas biotype $d$ strain Nissin is $83 \%$ homologous. The other reference organism to which the biotypes of $B$. thermophilum appear to be highly related is the neotype strain of $B$. ruminale, RU326: the similarity values were found to range from 60 to $72 \%$. Furthermore, the DNA from $B$. ruminale is $100 \%$ homologous to that of strain P2-91 (B. thermophilum biotype $a$ ).

$B$. pseudolongum biotypes $c$ and $d$ are genetically not distinct and are very closely related to the type strain of $B$. globosum, RU230 (70 and 65\%). Strain C10-45, B. longum subsp. animalis biotype $b$, is $100 \%$ homologous with $B$. pseudolongum but not with strain R101-8, thought to belong to biotype $a$ of the same subspecies; strain R 101-8 was not related to any of the species from animals.

Strain SU859 (B. suis) is not related genetically to any other strain in this study.

Relationships between "human" and "animal" species. Some competition tests were performed to substantiate at the genetic level the phenotypic unrelatedness between the species of Bifidobacterium found primarily in humans and those found in animal feces and rumens. On the basis of the results reported in Tables 3 and 4 , four strains were selected as reference organisms: S1 ( $B$. breve biotype $a$ ), E298-b (B. adolescentis biotype $c$ ), P2-91 ( $B$. thermophilum biotype $a$ ), and S3 (B. longum biotype $b$ ). The relative similarity values of the DNA from some competitor strains and the DNA of these reference strains are given in Table 5.

There was very insignificant DNA homology between strains from human and other animal sources even when phenotypic resemblances like those between $B$. breve and $B$. thermophilum, B. longum and B. pseudolongum, or $B$. longum subsp. animalis, existed. A good example of such unrelatedness was given by $B$. longum subsp. animalis and $B$. longum subsp. longum. $B$. longum subsp. animalis was proposed by Mitsuoka (27) as a subspecies (variety) of $B$. longum, a species so far found exclusively in the feces of man, on the basis of similar fermentative characters. However, neither biotype $a$ nor $b$ of $B$. longum subsp. animalis displays any homology with $B$. longum subsp. longum. Biotype $b$ is actually $B$. pseudolongum, and the relationships of biotype $a$ remain obscure.

These results (see Table 5) correlate well with data obtained from the migration rate of fructose-6-phosphate phosphoketolase in starch-gel electrophoresis (38).

Homology relationships among strains assigned to species of Bifidobacterium on a

TABLE 4. Deoxyribonucleic acid homology values among strains (including type strains) of Bifidobacterium species isolated from feces of various animals and bovine rumen ${ }^{a}$

\begin{tabular}{|c|c|c|c|c|c|c|c|}
\hline \multirow{2}{*}{\multicolumn{2}{|c|}{ Ccmpetitor strains }} & \multicolumn{6}{|c|}{ Reference strains } \\
\hline & & P2-91 & Mo2-10 & $\mathrm{C} 10-45$ & RU230 & RU326 & SU859 \\
\hline P2-91 & B. thermophilum biotype $a \ldots \ldots$ & 100 & 23 & 0 & 8 & 60 & 12 \\
\hline $14-44$ & B. thermophilum bioty pe $b \ldots \ldots \ldots$ & 100 & 9 & 14 & & 72 & 10 \\
\hline P16-6 & B. thermophilum biotype $c \ldots \ldots \ldots$ & 100 & 6 & 16 & 0 & 70 & 5 \\
\hline Nissin & B. thermophilum biotype $d \ldots \ldots \ldots \ldots$ & 83 & 0 & 0 & & 62 & 5 \\
\hline PNC-2-9G & B. pseudolongum biotype $a \ldots \ldots \ldots$ & 13 & 70 & 65 & 70 & 20 & 5 \\
\hline $29 \mathrm{SrT}$ & B. pseudolongum biotype $c \ldots \ldots \ldots$ & 14 & 100 & 100 & 70 & & 0 \\
\hline Mo2-10 & B. pseudolongum biotype $d \ldots \ldots \ldots \ldots$ & 23 & 100 & 90 & 65 & 13 & 0 \\
\hline $\mathrm{R} 101-8$ & B. longum subsp. animalis biotype $a \ldots \ldots \ldots$ & 9 & 34 & 30 & & 16 & 27 \\
\hline C10-45 & B. longum subsp. animalis biotype $b \ldots$ & 10 & 100 & 100 & 70 & 23 & 46 \\
\hline RU230 & B. globosum .............. & 10 & 75 & & 100 & 35 & 10 \\
\hline RU326 & B. ruminale $\ldots \ldots \ldots \ldots \ldots \ldots \ldots \ldots \ldots \ldots \ldots \ldots \ldots$ & 100 & 17 & & 30 & 100 & 5 \\
\hline SU859 & 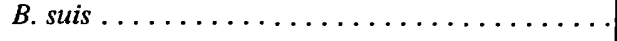 & & 0 & & 25 & 15 & 100 \\
\hline
\end{tabular}

$a_{\text {See footnote to Table } 3 .}$ 
TABLE 5. Deoxyribonucleic acid homology relationships between strains of some "human" and "animal" species of Bifidobacterium ${ }^{a}$

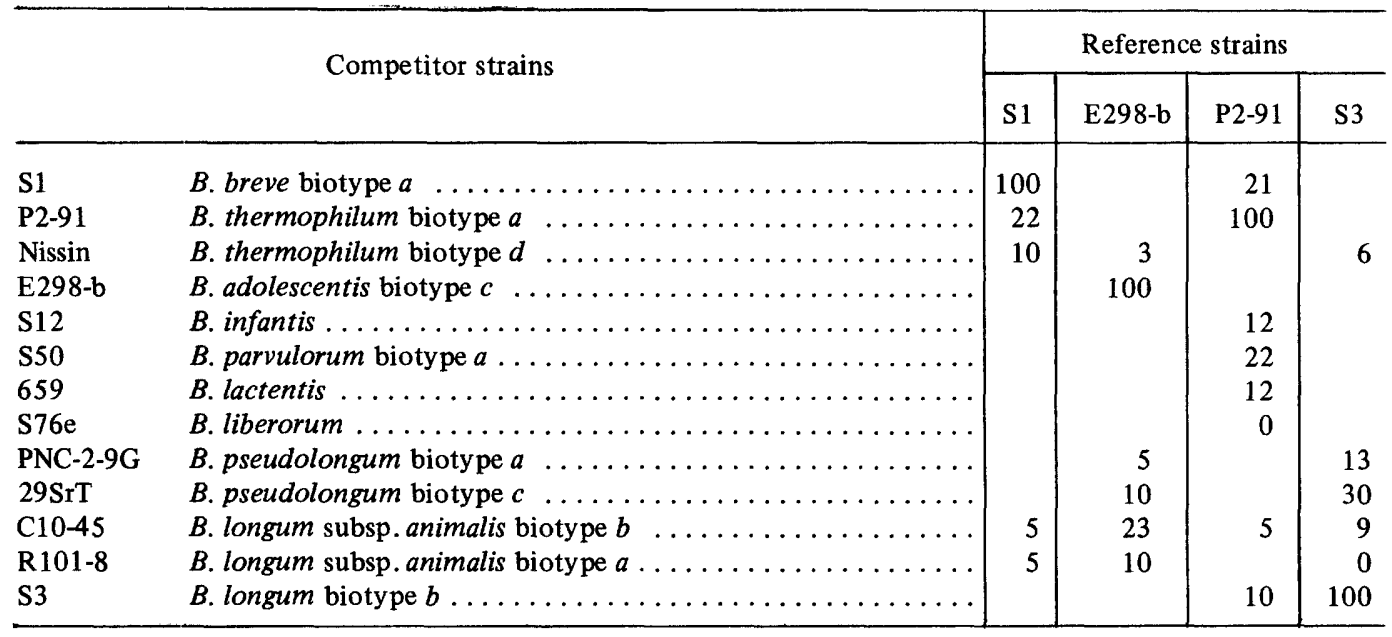

${ }^{a}$ See footnote to Table 3 .

phenotypic basis. DNA hybridization experiments can often lead to taxonomic misinterpretations when too few strains are employed, even if these are the type strains of the presumed species, especially when the phenotypic characters of these strains, like those of the bifidobacteria, are not too well known. Therefore, additional competition experiments were performed with the strains of our collection obtained from different habitats and identified as known species on the basis of morphology and fermentation patterns. This survey had two objectives: to assess the genetic homogeneity of the named species of Bifidobacterium and to determine whether there are groups of bifidobacteria with DNA-homology relationships not fitting the patterns which emerge from the study of the type strains.

The reference organisms used were selected with the results given in Tables 3 and 4 as guidelines. The strains used for the extraction of DNA competitors are listed in Table 2 .

Homology among strains identified as B. breve. The strains used were isolated from infants' feces and human vaginas and were assigned to $B$. breve because they fermented mannitol and sorbitol and not arabinose and xylose; biotypes $a$ and $b$ were distinguished on the basis of differences in trehalose and melezitose fermentations (Table 1). Contrary to the reports of Mitsuoka (27), many of our strains had the fermentation pattern of biotype $b$ but did not ferment cellobiose. The DNA-homology values of this group of strains with type strain
S1 ( $B$. breve biotype $a$ ) as reference are reported in Table 6.

Of 24 strains investigated, only two (B629

TABLE 6. Homology values of strains phenotypically identified as Bifidobacterium breve and measured with the type strain of $B$. breve as the reference organism ${ }^{a}$

\begin{tabular}{|c|c|}
\hline \multirow{2}{*}{ Competitor strains } & Reference \\
\hline & $\begin{array}{c}\text { S1 (type } \\
\text { strain) }\end{array}$ \\
\hline B. breve biotype $a$ strain $\mathrm{S} 1$ (type strain) & 100 \\
\hline B609; B624, from human feces ..... & $84-100$ \\
\hline B637; B648, from human feces... & $82-89$ \\
\hline B912; B943; B860, from & \\
\hline human vagina $\ldots \ldots \ldots$ & $62-89-82$ \\
\hline B. breve biotype $b$ S46 ... & 86 \\
\hline Cellobiose-positive strains & \\
\hline B622; B626, from human feces . & $62-86$ \\
\hline B628; B629, from human feces . . & $86-16$ \\
\hline B828; B862; B941, from & \\
\hline human vagina $\ldots \ldots \ldots \ldots$ & $83-87-85$ \\
\hline Cellobiose-negative strains & \\
\hline B627; B632; B633, from & \\
\hline human feces $\ldots \ldots \ldots \ldots$ & $100-100-82$ \\
\hline B64 1; B644, from human feces . & $4-86$ \\
\hline B799; B898, from human vagina & $82-75$ \\
\hline Unidentified strains & \\
\hline B721; B723, from human vagina & $90-91$ \\
\hline
\end{tabular}

${ }^{a}$ See footnote to Table 3. 
and B641 from feces) failed to demonstrate homology to $B$. breve $\mathrm{S} 1$ and remained unassigned at the end of multiple trials with all reference organisms. The remaining 22 strains, with the exception of B912 from the vagina and B622 from feces, gave values in the range of 75 to $100 \%$, thus demonstrating the high genetic homogeneity of this group of isolates as referred to the type strain of $B$. breve, regardless of the behavior toward cellobiose.

Also homologous to $B$. breve were two strains from the human vagina, i.e., B721 and B723; these strains are not phenotypically related to $B$. breve. They do not ferment mannitol and sorbitol and ferment arabinose but not xylose. This uncommon fermentation pattern, reminiscent of that reported by Malyoth and Bauer (22), is accompanied by some peculiarities in morphology that will be described in a later paper. No doubt these two strains are $B$. breve from a genetic standpoint.

Homology among strains identified as $B$. adolescentis. The phenotypic distinction between biotype $d$ of $B$. adolescentis and $B$. longum is based only upon the fermentation of cellobiose and glucosides (see Table 1); the biotypes $a, b$, and $c$ of $B$. adolescentis are better characterized by their behavior toward mannitol and sorbitol. We tested the fermentation of gluconate by strains of this species received from Reuter, viz. E194a, E305, E298b, H28, $\mathrm{H} 39 \mathrm{a}$, and H33. All of these strains fermented gluconate, and gas formation was easily observed by using the technique of Gibson and Abd-el-Malek (10). However, less acidity was produced than from glucose (45). From routine work on our own isolates from various sources, we concluded (40) that the fermentation of gluconate was a property shared by the species from honey bees and by the strains having the fermentation patterns of the biotypes of $B$. adolescentis; the mannitol-fermenting bifidobacteria from the bovine rumen, closely related genetically to $B$. adolescentis (3), ferment gluconate regularly. Therefore, the fermentation of gluconate was taken as an additional valuable tool in the selective work preliminary to the present study.

From isolates of our collection, obtained from human feces, vaginas, and dental caries, we selected for study 60 strains identified on fermentation patterns as $B$. adolescentis: 5 from infant feces, 17 from adult feces, 9 from vaginas, and 29 from dental caries. Six strains received from Mitsuoka and three from Reuter (besides the type and the reference strains from the same authors) were added to the list (see Table 2). The majority of our strains were assigned to biotype $b$ of $B$. adolescentis. Most strains were assayed for their DNA homology with Reuter's strain E298b (biotype $c$ ) as reference organism. The pertinent data are reported in Table 7.

It is immediately apparent that only a very few strains displayed high genetic relatedness to B. adolescentis, viz. $\mathrm{H} 28, \mathrm{H} 39 \mathrm{a}$, and $\mathrm{H} 33$ from Reuter; A205-14 and A216-21 from Mitsuoka; and B618 from our collection. It is striking that the vast majority of our isolates, mostly from dental caries but from human feces and from vaginas as well, displayed homologies never exceeding $50 \%$ to the reference strain used. Therefore, they are not $B$. adolescentis on a genetic basis. Our isolates from dental caries were extremely uniform from a phenotypic standpoint and fermented mannitol like the oral strains of Beerens, Gérard, and Guillaume (1).

To assess the genetic homogeneity of our large group of isolates, a second reference organism was used, strain B757 isolated from human feces and only $30 \%$ homologous with $B$. adolescentis strain E298b. The results reported in Table 7 show that the DNA from 41 strains displayed homologies with the new reference organism ranging from 69 to $105 \%$. Such strains form, therefore, a rather highly homogeneous group. This group, consisting of manritolfermenting strains (with only a very few exceptions), will be referred to hereafter as Unassigned Group "dentium" to indicate what seems to be one of the preferred habitats of these organisms. (We prefer to refer to our Unassigned Groups by latinized words instead of by numerals or letters to avoid confusion with the designations used for other groups or types reported in the literature).

The data in Table 7 fail however to indicate any genetic relatedness between 14 strains and the reference organism B757 (group "dentium"), i.e., the homology values rarely exceed $40 \%$. All these strains, some from human feces and some from vaginas, have the fermentation pattern of biotype $c$ of $B$. adolescentis. They characteristically ferment sorbitol. These strains may form a new genetically distinct group of bifidobacteria.

The cells of this second group of unassigned strains characteristically are arranged in irregular, sometimes long, chains and vigorously ferment sorbitol but not mannitol; they ferment gluconate as well. Several additional strains with these characters were found among a large number of bifidobacteria isolated from waste waters and muds and are now under study in our laboratory. These strains are 
TABLE 7. Deoxyribonucleic acid homologies among strains with the phenotype of Bifidobacterium adolescentis measured with $B$. adolescentis biotype $c$ strain E298b and strain $B 757$ as reference organisms ${ }^{a}$

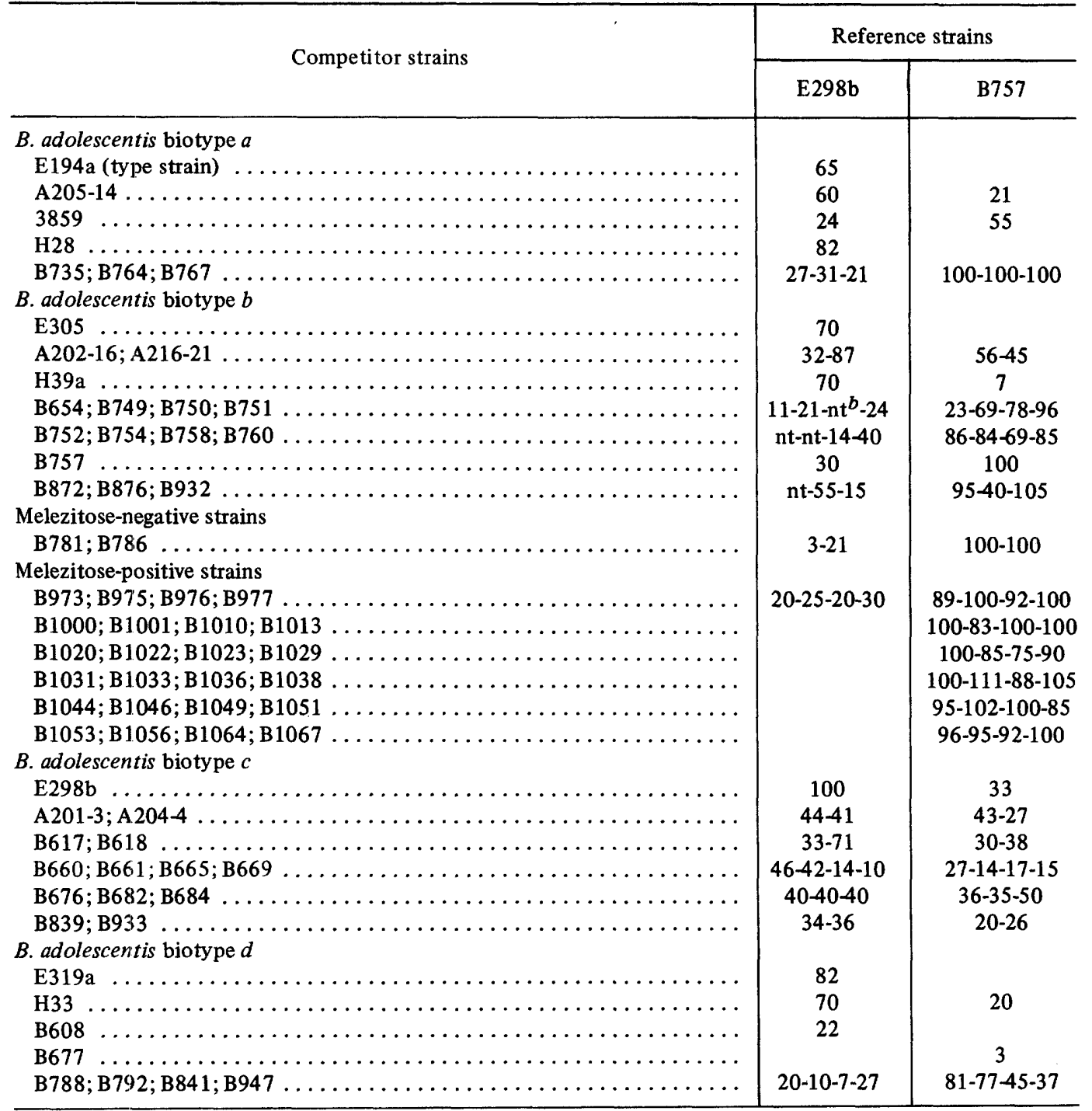

${ }^{a}$ See footnote to Table 3 .

$b$ Not tested.

tentatively referred to as Unassigned Group "catenulatum" because of the characteristic arrangement of their cells in chains.

B677, a strain isolated from feces from an adult, showed an unusual " $V$ " cell disposition under all cultural conditions; this disposition of the cells, strongly suggesting the "snapping" type of cell division in the genus Corynebacterium (17), has so far never been observed by us in any bifidobacterium except for some isolates from waste waters. These isolates and strain B677, all fermenting pentoses but not mannitol and sorbitol (they do not ferment gluconate), are placed in a third Unassigned Group, "angulatum," so-called because of the unique disposition of their cells.

The DNA-homology patterns of the aforementioned Unassigned Groups and the genetic relatedness between their reference strains and the selected competitor DNA from all known 
species of Bifidobacterium are reported in Table 8. It appears that the three Unassigned Groups, "dentium," "catenulatum," and "angulatum," are quite distinct genetically and do not share appreciable DNA polynucleotide sequence similarity with any of the named species of the genus Bifidobacterium. The general morphology and arrangement of the cells of organisms in the Unassigned Groups "dentium," "catenulatum," and "angulatum" are given in Fig. 1 to 6.

Homology among strains identified as $B$. longum. Biotypes $a$ and $b$ of $B$. longum are reported (see Table 1) characteristically not to ferment cellobiose, starch, and salicin. On the other hand, according to Mitsuoka (27), cellobiose is fermented very slowly by all biotypes of B. adolescentis. Starch fermentation is in general erratic among bifidobacteria. Mitsuoka (27) reported that melezitose is characteristically fermented by $B$. longum but only slowly fermented by $B$. adolescentis; this statement is not generally valid because our strains, genetically found to be $B$. longum (Table 9), do not ferment this carbohydrate. The behavior toward salicin and gluconate would probably be of more differential value. The bifidobacteria which ferment pentoses but not gluconate and salicin could be assigned to $B$. longum. Among our isolates only a few could be found to test for DNA homology with the type strain E194b and a reference strain $\mathrm{S} 3$ of $B$. longum; only one strain, B654, not assigned in the experiments with B. adolescentis (Table 7) was

TABLE 8. Deoxyribonucleic acid homology patterns of strains of the Unassigned Groups "dentium," "catenulatum," and "angulatum" a

\begin{tabular}{|c|c|c|c|c|}
\hline \multirow{2}{*}{\multicolumn{2}{|c|}{ Competitor strains }} & \multicolumn{3}{|c|}{ Reference strains of groups } \\
\hline & & $\begin{array}{c}\text { "dentium" } \\
\text { B764 }\end{array}$ & $\begin{array}{c}\text { "catenulatum" } \\
\text { B669 }\end{array}$ & $\begin{array}{c}\text { "angulatum" } \\
\text { B677 }\end{array}$ \\
\hline \multicolumn{5}{|c|}{ Unassigned group “dentium” } \\
\hline \multicolumn{2}{|c|}{ 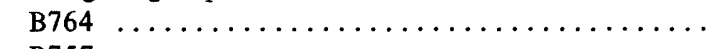 } & 100 & 20 & 5 \\
\hline \multicolumn{2}{|c|}{ В757 $\ldots \ldots \ldots \ldots \ldots \ldots \ldots \ldots$} & 93 & 27 & 3 \\
\hline \multicolumn{5}{|c|}{ Unassigned group "catenulatum" } \\
\hline \multicolumn{2}{|c|}{ B669 reference strain $\ldots \ldots \ldots \ldots \ldots \ldots \ldots \ldots \ldots \ldots$} & 27 & 100 & 23 \\
\hline \multicolumn{2}{|c|}{ 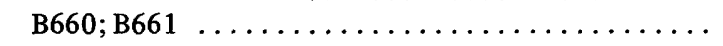 } & $25-15$ & $97-97$ & $26-37$ \\
\hline \multicolumn{2}{|c|}{ B676;B684 $\ldots \ldots \ldots \ldots \ldots \ldots \ldots \ldots$} & $35-50$ & $95-100$ & \\
\hline \multicolumn{2}{|c|}{ F71;F81 $\ldots \ldots \ldots \ldots \ldots \ldots \ldots \ldots \ldots \ldots$} & $28-34$ & $73-68$ & $33-33$ \\
\hline \multicolumn{2}{|c|}{ 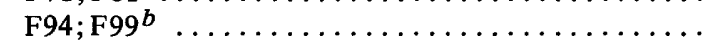 } & $33-21$ & $78-65$ & $31-34$ \\
\hline \multicolumn{2}{|c|}{ 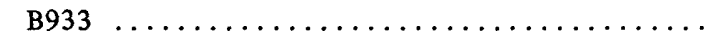 } & & 70 & 35 \\
\hline \multicolumn{5}{|c|}{ Unassigned group "angulatum" } \\
\hline \multicolumn{2}{|c|}{ B677 reference strain $\ldots \ldots \ldots \ldots \ldots \ldots$} & 5 & 28 & 100 \\
\hline \multicolumn{2}{|c|}{ F92; F158; F196 $\ldots \ldots \ldots \ldots \ldots \ldots \ldots \ldots$} & $27-8-10$ & $60-35-35$ & $77-90-80$ \\
\hline \multicolumn{2}{|c|}{ 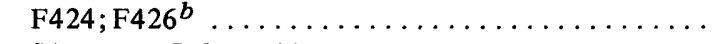 } & $15-20$ & $25-20$ & $76-83$ \\
\hline S1 & B. breve biotype $a \ldots \ldots \ldots \ldots$ & 10 & 14 & 16 \\
\hline $\mathrm{S} 12$ & B. infantis $\ldots \ldots \ldots \ldots \ldots \ldots$ & 25 & 28 & 13 \\
\hline S50 & B. parvulorum biotype $a \ldots \ldots \ldots$ & 4 & 15 & 32 \\
\hline $\mathrm{S} 76 \mathrm{e}$ & B. liberorum ............... & 26 & 12 & 20 \\
\hline 659 & B. lactentis $\ldots \ldots \ldots \ldots \ldots \ldots$ & 13 & 30 & 30 \\
\hline S28a & B. bifidum biotype $b \ldots \ldots \ldots \ldots$ & 4 & 17 & 5 \\
\hline $\mathrm{E} 298 \mathrm{~b}$ & B. adolescentis biotype $c \ldots \ldots \ldots$ & 10 & 40 & 0 \\
\hline RU326 & 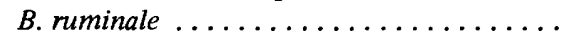 & 20 & 26 & 23 \\
\hline SU859 & 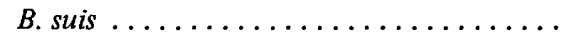 & 12 & 38 & 28 \\
\hline RU230 & B. globosum $\ldots \ldots \ldots \ldots \ldots \ldots$ & 15 & 0 & 24 \\
\hline P2-91 & B. thermophilum biotype $a \ldots \ldots \ldots$ & 17 & 23 & 27 \\
\hline Mo2-10 & B. pseudolongum biotype $d \ldots \ldots \ldots$ & 28 & & 10 \\
\hline E194b & B. longum biotype $a \ldots \ldots \ldots \ldots$ & 12 & 15 & 7 \\
\hline S3 & B. longum biotype $b \ldots \ldots \ldots \ldots$ & 28 & 27 & 38 \\
\hline
\end{tabular}

a See footnote to Table 3 .

${ }^{b}$ Not all the data obtained with the strains from waste waters (see Table 2) are reported in this table. 


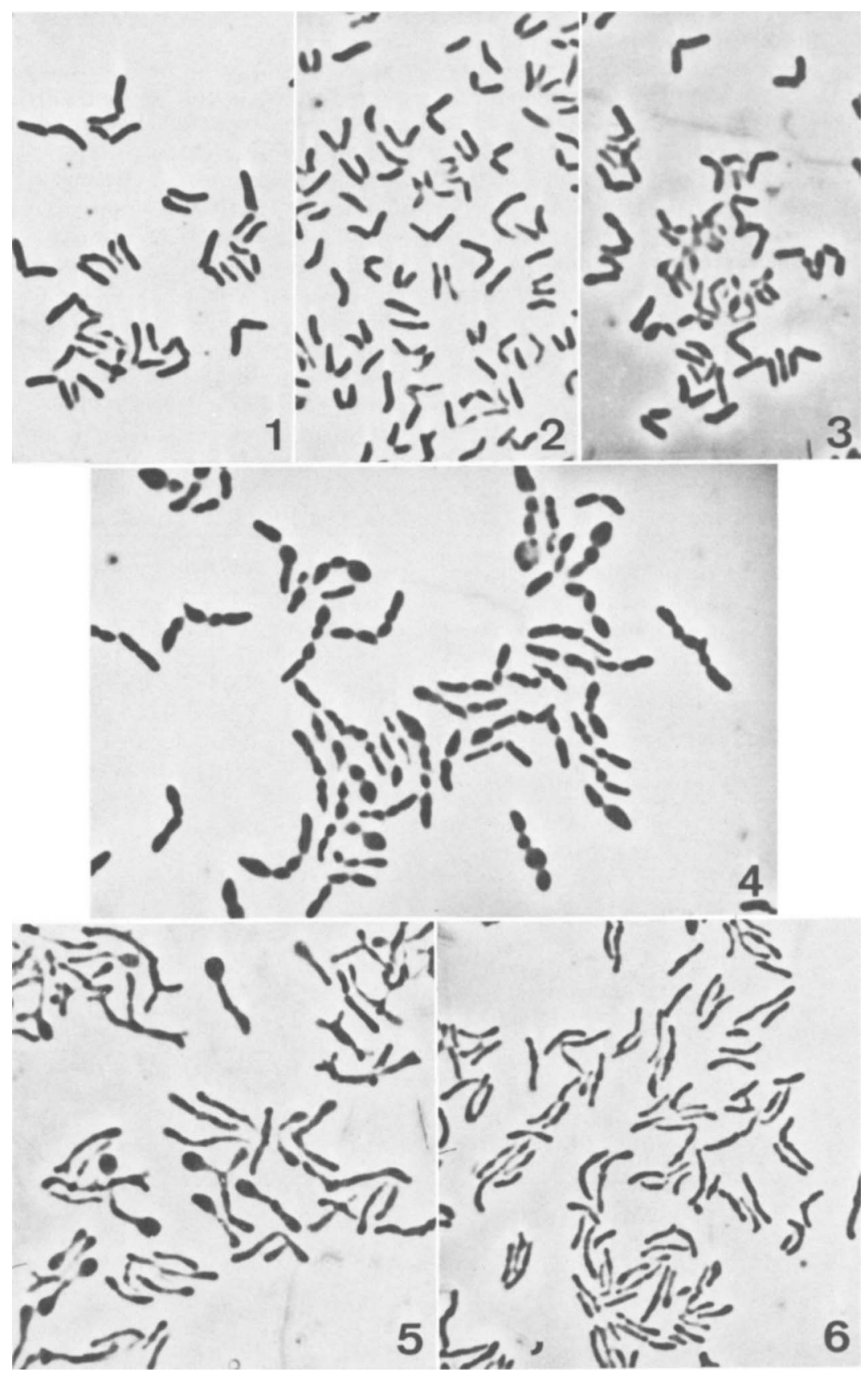

FIG. 1-6. Morphology of unassigned groups. Fig. 1-3. Group "angulatum" strains F424, B677 (reference strain), and F196. Fig. 4. Group "catenulatum" strain B669 (reference strain). Fig. 5 and 6. Group "dentium" strains B757 and B764. Cells from anaerobic stabs in Trypticase-Phytone-yeast extract-glucose medium. Phase contrast. $\times 1,500$. 
included in this group of isolates. The results are given in Table 9. Although the homology values were not so high as in preceding groups, it should be noted that, except for strain B686 which remained unassigned in this work, the strains tested as competitors displayed an homology level to $B$. longum biotype $a$ very close to that of strain S3 of $B$. longum biotype $b$. All our strains, however, do not ferment mannose. Therefore, they should be considered closer phenotypically to $B$. longum biotype $a$ than to $B$. longum biotype $b$; the data reported in Table 9 indicate that the homology values of the group are higher when they are measured in the homologous system of strain S3 ( $B$. longum biotype $b$ ).

\section{DISCUSSION}

McCarthy and Bolton (21) and Hoyer et al. (14) showed that competition reactions, wherein the interference of nonlabeled DNA fragments in binding of labeled DNA to homologous DNA is measured, provides a means for assessing DNA interactions with a minimal number of experimental variables. Annealing of single-strand DNA with fixed reference DNA must, however, be carried out under "stringent" conditions, i.e., those permitting only specific pairing of complementary polynucleotide sequences.

The temperature of duplex formation is one of the critical parameters in the formation of specific complementary double strands (15, 20). Theoretically, with increasing "stringent" conditions (i.e., at temperatures at least $25 \mathrm{C}$ below $T_{m}$ ) as recognized first by Marmur and Doty (24), one selects against imperfections of annealing. Precoating the cellulose-nitrate membranes with the albumin-polymer solution of Denhardt (6) lowers the amount of unspecific attachments. In the present study, these requirements were satisfied, and the true degree of relatedness was therefore evaluated. The fact that relatedness in the range from 0 to $100 \%$ was assessed among organisms like those studied here, all falling in a very narrow range of per cent GC (60 to 65), is a confirmation of this assumption. The reasonably good agreement of relative relatedness in all reciprocal reactions seems to rule out gross differences in genome size. Recently, however, De Ley and Tijtgat (5) drew attention to the spontaneous release of DNA from filters at high temperatures; the high temperatures required, even at $25 \mathrm{C}$ below $\mathrm{T}_{\mathrm{m}}$, could not be suitable for organisms with over $65 \% \mathrm{GC}$. In the range of 50 to $65 \% \mathrm{GC}$, the reliability of the results obtained with the procedure of Denhardt (6) should depend on the quality of the filter. We experienced some difficulties in obtaining good filters with some DNA, irrespective of the amount of DNA fixed; spontaneous release of DNA during incubation cannot be excluded. In many of these cases "Selectron" filters were used preferably (see above).

The results obtained by DNA-binding experiments are generally trusted when they correlate reasonably with the taxonomic groupings deter-

TABLE 9. Homology values of strains phenotypically identified as Bifidobacterium longum measured with the type strain of $B$. longum and strain $S 3$ as reference organisms ${ }^{a}$

\begin{tabular}{|c|c|c|}
\hline \multirow[b]{2}{*}{ Competitor strains } & \multicolumn{2}{|c|}{ Reference strains } \\
\hline & $\begin{array}{c}\mathrm{E} 194 \mathrm{~b} \\
\text { (type strain) }\end{array}$ & S3 \\
\hline B. longum biotype $a$ E194b (type strain) & 100 & 70 \\
\hline $\begin{array}{l}\text { B. longum biotype } b \mathrm{~S} 3 \ldots \ldots \ldots \ldots \ldots \ldots \\
\text { Strains isolated from feces of infants: }\end{array}$ & 75 & 100 \\
\hline B612;B647 $\ldots \ldots \ldots \ldots \ldots \ldots$ & $70-68$ & $71-80$ \\
\hline B686; B688 $\ldots \ldots \ldots \ldots \ldots \ldots \ldots \ldots$ & $25-60$ & $20-73$ \\
\hline Strains isolated from human vaginas: & & \\
\hline B800; B821 $\ldots \ldots \ldots \ldots \ldots \ldots \ldots \ldots$ & $70-87$ & $85-92$ \\
\hline B923; B929 $\ldots \ldots \ldots \ldots \ldots \ldots \ldots \ldots \ldots$ & $67-67$ & $85-86$ \\
\hline Strain isolated from feces of adult: & & \\
\hline $\mathrm{B} 654^{b} \ldots \ldots \ldots \ldots \ldots$ & 65 & 71 \\
\hline
\end{tabular}

${ }^{a}$ See footnote to Table 3 .

${ }^{b}$ Not assigned in the preceding experiments (see Table 7). 
mined by classical methods or better by taxometric analysis $(2,13)$. It must be remembered, however, that the DNA-DNA hybridization technique takes into account the entire genome, whereas taxometric analysis involves only those parts of it whose phenotypic expression can be measured (13); furthermore, similar enzymatic expressions may result from enzymes containing quite different amino-acid sequences. In the case of the bifidobacteria, there are probably insufficient characters to permit extensive taxometric analyses. At present, the DNA homology approach in the study of the taxonomy of the bifidobacteria, as well as in other newly discovered and incompletely examined microorganisms, seems to be the method of choice; it serves not only to confirm the validity of species at the genetic level but also to pave the way for fruitful comparative physiological and biochemical investigations with genetically homogeneous bacterial populations.

B. bifidum. B. bifidum is the most easily recognized species of Bifidobacterium because of its characteristic fermentation pattern (see Table 1). Kandler (16) found in five isolates of this species and in Lactobacillus bifidus subsp. pennsylvanicus ATCC 11863 the same characteristic murein. Although few strains of this species were investigated here, the results were striking. Strains E319f and S28a, almost identical phenotypically but isolated from feces from an adult and an infant, respectively, are $100 \%$ homologous; three other isolates from the human vagina and $L$. bifidus subsp. pennsylvanicus are $100 \%$ homologous and are also homologous to either of two reference organisms. Little if any similarity was found relative to other species of the genus Bifidobacterium. The validity of this species is therefore undeniable. However, its homogeneity should be better assessed with the study of more strains.

B. infantis, B. liberorum, and B. lactentis. Although differing reports have been given (44), most pertinent literature data indicate that $B$. infantis, $B$. liberorum, and $B$. lactentis are the predominant bifidobacteria in the feces of breast-fed infants. Dehnert (thesis, Universitäts-Kinderklinik, Heidelberg, 1961; reference 4), Petuely and Lindner (32), Liebscher (19), Gyllenberg and Carlberg (11), Müller and Pech (29), and Haenel et al. (12) generally recognize as "Brustkind-Bifidus" the bifidobacteria which ferment xylose and mannitol [nutritional type A of Gyllenberg and Carlberg (11), group IV Dehnert (4)]. Reuter (36) named this type $B$. lactentis (Table 1). Reuter further distinguished as $B$. liberorum a novel xylose-positive type similar to $B$. lactentis; however, $B$. liberorum does not ferment mannitol; the strong phenotypic relatedness of $B$. liberorum and biotype $c$ of Dehnert's group IV (J. Dehnert, thesis, Universitäts-Kinderklinik, Heidelberg, 1961) was recognized by Reuter (36). He also found a biotype he named $B$. infantis which did not ferment pentoses and polyols (Table 1) and which was very similar in morphology to $B$. liberorum. Although they were distinct serologically, Reuter stated that between $B$. infantis and $B$. lactentis "...gewisse Beziehungen hinsichtlich von Teilantigenen bestehen" (36, p. 494). A biotype of $B$. infantis was found by Mitsuoka (27) (B. infantis type $b)$ which ferments inositol like $B$. liberorum and $B$. lactentis (Table 1). Some fermentation characters are thus apparently common to these three species: slow fermentation of ribose and mannose, no reaction with cellobiose or melezitose, fermentation of inulin and inositol, and similar behavior toward glucosides.

Our results, obtained with the type strains of these species, clearly indicate the close genetic relatedness existing among these strains. $B$. infantis strain $\mathrm{S} 12$ is 77 and $92 \%$ homologous with $B$. liberorum and $B$. lactentis (see last two columns of Table 3 ), and these species are 77 and $70 \%$ similar to the type strain S12 of $B$. infantis. Although this group will be circumscribed with more confidence when larger numbers of strains are examined, the proposal is made here to merge $B$. infantis, $B$. liberorum, and $B$. lactentis into a single species, for which the name $B$. infantis should be used because it has priority (page priority) over the other two names.

Bifidobacterium parvulorum and B. breve. $B$. parvulorum biotype $a$ and $B$. breve were the designations given by Reuter (36) to bifidobacteria corresponding to biotypes $b$ and $a$, respectively, of the group III established by Dehnert (thesis, Universitäts-Kinderklinik, Heidelberg, 1961). Reuter named as $B$. parvulorum biotype (variety) $b$ an organism isolated from feces from an infant and subsequently referred to as a new type (type 6) by Werner and Seeliger (46); these are also found in the human vagina. No doubt these "types," separated on the basis of fermentation characters, have much in common in their morphology, serology, and probably ecology. They are apparently abundant in the feces of infants where, especially $B$. parvulorum biotype $a$ "... schien in mehreren Fällen der Ersatz für den zurückgehenden Typ IV (B. infantis) zu sein" (36, p. 492). Their serological relatedness has been recognized by Reuter (36). Our results indicate that these 
types are strongly related genetically (more than $86 \%$ homology, see Table 3 ) and that many strains behaving phenotypically like $B$. breve share most polynucleotide sequences of their DNA (Table 6). Of 21 strains tested (each isolated from a different specimen), only 2 (strains B629 and B641) were not identifiable with any named species.

Many of the strains tested were cellobiosenegative; Reuter (36), Mitsuoka (27), and Dehnert (4) reported on the contrary that cellobiose was characteristically fermented by the strains of this type. Once again this strengthens the notion that some fermentation characters may be of little value in the speciation of the genus Bifidobacterium. A clear example was offered by the strains isolated from the bovine rumen which, although fermenting pentoses and mannitol, are 85 to $90 \%$ homologous with $B$. globosum, a species which does not ferment these compounds (3). Although we did not test mannitol- and sorbitolnegative isolates which could be assigned to $B$. parvulorum (Table 1), the most logical conclusion to be drawn from our DNA homology experiments is to merge $B$. breve and $B$. parvulorum into a single species, $B$. breve, this name having priority over $B$. parvulorum. Other phenotypic types described by Malyoth and Bauer (22), such as those fermenting arabinose but not xylose, probably belong to this species (see our strains B721 and B723 in Table 6). Phenotypic characters that might be used for identifying this species require further consideration.

B. longum. B. longum, sometimes found in the feces of infants (Dehnert's group V), predominates together with $B$. adolescentis in the feces of adults. Here again Reuter (36) distinguished a biotype (variety) $a$, mostly found in adults, and a biotype $b$, predominating in the feces of infants. The level of genetic similarity between these two biotypes is apparently lower than that between the biotypes of any other bifidobacteria.

Our isolates, phenotypically closer to biotype $a$ but isolated from feces of infants and vaginas, seem to be more related genetically to biotype $b$ (Table 9); this could be perhaps more in accord with their ecology. B. longum is clearly distinct genetically from the other bifidobacteria, and hence its validity as a species is confirmed. A certain degree of relatedness seems to exist between $B$. longum and the group $B$. infantis-liberorum-lactentis. The similarity values of these last three species tested as competitors in the reactions with $B$. longum biotype $b$ are 60,50 , and $46 \%$, respec- tively. This interesting point merits further experimental work. $B$. bifidum and $B$. adolescentis (see below) are far less related to $B$. longum. The distinction of a subspecies (variety) ( $B$. longum subsp. animalis) in the species $B$. longum as suggested by Mitsuoka (27) did not find any experimental support. Strain C10-45 (type $b$ of Mitsuoka's subspecies) is evidently $B$. pseudolongum, and strain R101-8 (type $b$ of the same subspecies) remained unassigned to any species. The electrophoretic behavior of fructose-6-phosphate phosphoketolase of strain $\mathrm{C} 10-45$ was found to fit its DNA-homology pattern. The migration rate of this enzyme in starch electrophoresis was found to be identical to that of $B$. pseudolongum and other species from animals and very different from that of $B$. longum and other species from human sources (38).

B. adolescentis and unassigned groups. Reuter (36) named as $B$. adolescentis those pentose-fermenting bifidobacteria he first found to predominate, along with $B$. longum, in the feces of adults; he distinguished four biotypes (varieties), $a, b, c$, and $d$, differing in their fermentation patterns and serological behavior. Mitsuoka (27) also distinguished four biotypes and confirmed the ecology of this species. The genetic validity of the species $B$. adolescentis was confirmed by the DNA sequence similarity among the reference strains of the biotypes proposed by Reuter and a few other strains (Table 7). From a practical point of view, however, the phenotype of this species must be carefully assessed and compared with that of the Unassigned Groups discussed below.

The results we obtained with a rather large number of strains isolated from human feces, vaginas, dental caries, and waste waters demonstrated that the fermentation patterns of $B$. adolescentis and its biotypes are actually displayed by at least three additional bacterial groups distantly related genetically from each other and from other genetic species of the genus Bifidobacterium (Tables 7 and 8).

The heterogeneity of $B$. adolescentis had previously been indicated. Kandler (16) found different types of murein and varying ornithinelysine ratios in different strains of this species, and some differences in DNA homology relationships were noted by Crociani et al. (3).The amplitude of the divergencies, however, was quite unexpected. The recognition of the existence of sharply distinct genetic groups within the phenotype of $B$. adolescentis, referred to here as the "dentium," "catenulatum," and "angulatum" groups, may help in resolving 
some of the problems of bifidobacteria taxonomy.

The mannitol-fermenting strains isolated by Beerens, Gérard, and Guillaume (1) from the human mouth might be related to our Unassigned Group "dentium." We found these unique organisms in dental caries; this type is present, however, also in the feces of adults and in the vagina. The sorbitol-fermenting bifidobacteria isolated by Orla-Jensen et al. (31) from human feces may well be related to our Unassigned Group "catenulatum." Our preliminary records indicate that strains of this group are abundant in waste waters or muds; whether these organisms can withstand extrabody conditions of proliferate in these habitats is a question that merits further investigation. Our strains display the biochemical characters of true bifidobacteria; hence, they probably do not have anything in common with the pleomorphic, chain-forming, anaerobic bacteria found by Lerche and Reuter (18) or with the "Kettenformige Bifidobakterien" referred to by Mitsuoka, Sega, and Yamamoto (28), bacterial forms which are being assigned to the genus Catenabacterium (Kandler and Mitsuoka, personal communication).

Our Unassigned Group "angulatum" merits comment. Its morphology (Fig. 1-3) has never been observed before in bifidobacteria, and the cell disposition suggests a type of division apparently unknown in this group of bacteria (see above). The strains we studied were identified as bifidobacteria on the basis of their overall metabolism and biochemistry; the reference strain B677 possesses a "human" electrophoretic type of fructose-6-phosphate phosphoketolase (38; Scardovi, unpublished data) and a per cent GC of $59.0 \pm 0.12$. Only one strain (strain B677) was isolated from human feces; others, although not numerous, were found in waste waters. A particular ecology is thus indicated.

A small number of strains phenotypically assigned to $B$. adolescentis were not related genetically to any of the reference organisms used in this work. Among these were strains $\mathrm{B} 617$, B665, and B682, all assigned phenotypically to biotype $c$ of $B$. adolescentis. In a previous study by Crociani et al. (3), a group of mannitol-fermenting bifidobacteria isolated from rumens (reference strain: RU424) was found closely related genetically to some bifidobacteria from feces of humans and having the fermentation pattern of $B$. adolescentis biotype $c$. These "human" strains were B617, B665 and B682 (3 and Table 3).

The electrophoretic pattern of fructose-6- phosphate phosphoketolase of strain RU424 (38), as well as its uniform murein type, Lys-Asp (Kandler, personal communication), confirmed this relatedness. All of this could be taken as evidence for the existence of an additional group of bifidobacteria genetically distinct from but having a fermentation pattern similar to that of $B$. adolescentis; additional work is needed to elucidate this point.

$B$. ruminale and $B$. thermophilum. $B$. ruminale and $B$. thermophilum cannot be distinguished on the basis of DNA homology (Tables 4 and 10). B. ruminale strains exhibit the same range of homology when tested as competitors in the systems RU326 (B. ruminale neotype strain) and P16-6 (B. thermophilum biotype $c$ ). There is also great phenotypic similarity. The fermentation patterns are identical (Table 1); both B. ruminale and $B$. thermophilum ferment ribose, a sugar not tested in previous work on bifidobacteria from the rumen (41). Lactose-fermenting strains were found in $B$. ruminale (see B. ruminale $\mathrm{R}$ in Table 10). Kandler (personal communication) found that $B$. thermophilum and $B$. ruminale have the same murein type, with D-glutamic acid as the only constituent of the interpeptide bridge. The only distinguishing character is that $B$. thermophilum can grow at $46.5 \mathrm{C}$, whereas $B$. ruminale cannot. It is doubtful whether these two species are separate specific taxa, and they should be merged into a single species. The correct name of this species remains to be determined, both $B$. thermophilum and $B$. ruminale having been published in 1969 .

B. pseudolongum and B. globosum. As in the preceding case, high levels of genetic relatedness were detected between $B$. pseudolongum and $B$. globosum. There was 78 to $106 \%$ homology between our strains of $B$. globosum and strain RU230 as reference, and 69 to $73 \%$ with $B$. pseudolongum biotype $c$, strain Mo2-10 as reference. However, these data (Table $10)$ indicate that the genetic homology between these two species is not so great as that between $B$. ruminale and $B$. thermophilum. Nevertheless, $B$. pseudolongum and B. globosum have many common phenotypic traits. The characteristic shape (short to coccoid rods) of the cells of $B$. globosum, aptly described by the specific epithet [see photographs in Scardovi et al. (41)], appears also to be a trait of both $B$. pseudolongum and $B$. longum subsp. animalis.

B. globosum does not ferment pentoses. However, Crociani et al. (3) found that, among mannitol-fermenting bifidobacteria from the rumen, many isolates were genetically like $B$. globosum but fermented pentoses like $B$. 
TABLE 10. Deoxyribonucleic acid homology relationships of Bifidobacterium ruminale, $B$. globosum, $B$. thermophilum, and $B$. pseudolongum ${ }^{a}$

\begin{tabular}{|c|c|c|c|c|c|}
\hline \multirow{2}{*}{\multicolumn{2}{|c|}{ Competitor strains }} & \multicolumn{4}{|c|}{ Reference strains } \\
\hline & & RU326 & RU230 & P16-6 & Mo2-10 \\
\hline \multicolumn{6}{|c|}{ B. ruminale strains } \\
\hline RU326 & $\ldots \ldots \ldots \ldots \ldots \ldots \ldots$ & 100 & 30 & 71 & 27 \\
\hline RU263 & $\ldots \ldots \ldots \ldots \ldots \ldots$ & 86 & 15 & 74 & 23 \\
\hline RU268 & $\ldots \ldots \ldots \ldots \ldots \ldots$ & 88 & 14 & 74 & 8 \\
\hline RU279 & $\ldots \ldots \ldots \ldots \ldots \ldots$ & 62 & 0 & 69 & 2 \\
\hline RU290 & $\ldots \ldots \ldots \ldots \ldots \ldots$ & 70 & 50 & 72 & 6 \\
\hline RU356 & $\ldots \ldots \ldots \ldots \ldots \ldots \ldots$ & 85 & 0 & 77 & 15 \\
\hline RU381 & $\ldots \ldots \ldots \ldots \ldots \ldots \ldots$ & 83 & 19 & 84 & 12 \\
\hline RU417 & $\ldots \ldots \ldots \ldots \ldots \ldots \ldots$ & 42 & 30 & & 46 \\
\hline RU431 & $\ldots \ldots \ldots \ldots \ldots \ldots \ldots$ & 98 & 15 & 79 & 10 \\
\hline \multirow[t]{2}{*}{ RU445 } & $\ldots \ldots \ldots \ldots \ldots \ldots \ldots$ & 96 & 17 & 84 & 23 \\
\hline & (range) & $62-98^{b}$ & $0-50^{b}$ & $69-84$ & $2-27^{b}$ \\
\hline \multicolumn{6}{|c|}{ B. globosum strains } \\
\hline RU224 ( & type strain) $\ldots \ldots \ldots \ldots$ & 30 & 78 & 50 & 72 \\
\hline RU230 & $\ldots \ldots \ldots \ldots \ldots \ldots$ & 35 & 100 & 36 & 71 \\
\hline RU240 & $\ldots \ldots \ldots \ldots \ldots \ldots$ & 39 & 94 & 38 & 73 \\
\hline RU255 & $\ldots \ldots \ldots \ldots \ldots \ldots$ & 30 & 106 & 38 & 69 \\
\hline RU256 & $\ldots \ldots \ldots \ldots \ldots \ldots \ldots$ & 18 & 92 & 20 & 69 \\
\hline RU257 & $\ldots \ldots \ldots \ldots \ldots \ldots$ & 25 & 92 & 26 & 72 \\
\hline RU323 & $\ldots \ldots \ldots \ldots \ldots \ldots$ & 54 & 95 & 42 & 73 \\
\hline \multirow[t]{2}{*}{ RU457 } & $\ldots \ldots \ldots \ldots \ldots \ldots \ldots$ & 34 & 82 & 30 & 73 \\
\hline & (range) & $18-54$ & 78.106 & $20-50$ & $69-73$ \\
\hline \multicolumn{6}{|c|}{$B$. ruminale $R$ strains } \\
\hline RU276 & $\ldots \ldots \ldots \ldots \ldots \ldots$ & 64 & 5 & 70 & 0 \\
\hline RU348 & $\ldots \ldots \ldots \ldots \ldots \ldots$ & 64 & 10 & 65 & 5 \\
\hline RU354 & $\ldots \ldots \ldots \ldots \ldots \ldots$ & 70 & 5 & 70 & 5 \\
\hline B. thermot & hilum biotype $c$ P16-6 .. & 70 & 5 & 100 & 6 \\
\hline B. pseudol & ongum biotype $d \mathrm{Mo} 2-10$ & 13 & 70 & 20 & 100 \\
\hline
\end{tabular}

a See footnote to Table 3 .

$b$ Value of strain R417, previously not identified, was omitted.

pseudolongum. Mitsuoka (27) did not record any pentose-negative strains of $B$. pseudolongum. Some strains of $B$. pseudolongum were isolated from sheep and bovine rumens (27), habitats where $B$. globosum proliferates. Kandler (personal communication) found the same murein type, L-Orn (or L-Lys)- (L-Ala) 3 , in both species. The two species diverge, however, in their DNA base composition. In Mitsuoka's strains C10-45 (B. longum subsp. animalis biotype b), PNC-2-9G, 29SrT, and Mo2-10 (B. pseudolongum biotypes $a, c$ and $d$, respectively) we found the values $59.7 \pm 0.28$, $59.5 \pm 0.36,59.9 \pm 0.69$, and $61.1 \pm 0.47$, respectively. In $B$. globosum, previously reported (41) as having a higher per cent GC, we confirmed the value of $63.80 \pm 0.40$.

We feel, therefore, some reluctance to con- clude that these two species are identical; it seems more advisable to investigate further their similarity at the macromolecular level before drawing definite conclusions.

\section{ACKNOWLEDGMENTS}

We are grateful to G. Reuter, Institut für Lebensmittelhygiene der Freien Universität, Berlin, and to T, Mitsuoka, Institute of Physical and Chemical Research, Yamato-Machi, Japan, for the bacterial strains received, and to $O$. Kandler, Botanisches Institut der Universität, München, for information and advice.

This investigation was supported by a research grant of Consiglio Nazionale delle Ricerche, Roma.

\section{LITERATURE CITED}

1. Beerens, H., A. Gérard, and J. Guillaume. 1957. Étude de 30 souches de Bifidobacterium bifidum (Lactobacillus bifidus). Caractérisation 
d'une variété buccale. Comparaison avec les souches d'origine fécale. Ann. Inst. Pasteur Lille 9:77-85.

2. Citarella, R. V., and R. R. Colwell. 1970. Polyphasic taxonomy of the genus Vibrio: polynucleotide sequence relationships among selected Vibrio species. J. Bacteriol. 104:434-442.

3. Crociani, F., V. Scardovi, and L. D. Trovatelli. 1970. Mannitol fermenting bifids from rumen and their DNA homology relationships. Ann. Microbiol. 20: 99-106.

4. Dehnert, J. 1957. Untersuchung über die grampositive Stuhlflora des Brustmilchkindes. Zentralbl. Bakteriol. Parasitenk. Infektionskr. Hyg. Abt. I. Orig. 169:66-79.

5. De Ley, I., and R. Tijtgat. 1970. Evaluation of membrane filter methods for DNA-DNA hybridization. Antonie van Leeuwenhoek J. Microbiol. Serol. 36:461-474.

6. Denhardt, D. T. 1966. A membrane-filter technique for the detection of complementary DNA. Biochem. Biophys. Res. Commun. 23:641-646.

7. de Vries, W., S. J. Gerbrandy, and A. H. Stouthamer. 1967. Carbohydrate metabolism in Bifidobacterium bifidum. Biochim. Biophys. Acta 136:415-425.

8. de Vries, W., and A. H. Stouthamer. 1969. Factors determining the degree of anaerobiosis of Bifidobacterium strains. Arch. Mikrobiol. 65:275 - 287 .

9. Exterkate, F. A., and J. H. Veerkamp. 1969. Biochemical changes in Bifidobacterium bifidum var. pennsylvanicus after cell wall inhibition. I. Composition of lipids. Biochim. Biophys. Acta (Amst.) 175:65-77.

10. Gibson, T., and Y. Abd-el-Malek. 1945. The formation of carbon dioxide by lactic acid bacteria and Bacillus licheniformis and a cultural method of detecting the process. J. Dairy Res. $14: 35-44$.

11. Gyllenberg, H., and G. Carlberg. 1958. The dominance of a specific nutritional type of Lactobacillus bifidus in breast-fed infants. Acta Pathol. Microbiol. Scand. 42:380-384.

12. Haenel, H., W. Müller-Beuthow, and F. K. Grütte. 1970. Zur fäkalen Mikroökologie des Säuglings in Abhängigkeit von der Ernährung: Zusammensetzung der Mikroflora sowie vorkommen der Lactobacillus bifidus-Typen. Zentralbl. Bakteriol. Parasitenk. Infektionskr. Hyg. Abt. I. Orig. 215:333-347.

13. Heberlein, G. T., J. De Ley, and R. Tijtgat. 1967. Deoxyribonucleic acid homology and taxonomy of Agrobacterium, Rhizobium, and Chromobacterium. J. Bacteriol. 94:116-124.

14. Hoyer, B. H., B. J. McCarthy, and E. T. Bolton. 1964. A molecular approach in the systematics of higher organisms. Science (London) 144:959-967.

15. Johnson, J. L., and E. J. Ordal. 1968. Deoxyribonucleic acid homology in bacterial taxonomy: effect of incubation temperature on reaction specificity. J. Bacteriol. 95:893-900.
16. Kandler, O. 1970. Amino acid sequence of the murein and taxonomy of the genera Lactobacillus, Bifidobacterium, Leuconostoc, and Pediococcus. Int. J. Syst. Bacteriol. 20:491-507.

17. Komagata, K., K. Yamada, and H. Ogawa. 1969. Taxonomic studies on coryneform bacteria. I. Division of bacterial cells. J. Gen. Appl. Microbiol. 15:243-259.

18. Lerche, M., and G. Reuter. 1961. Isolierung und Differenzierung anaerober Lactobacilleae aus dem Darm erwachsener Menschen (Beitrag zum Lactobacillus bifidus-Problem). Zentralbl. Bakteriol. Parasitenk. Infektionskr. Hyg. Abt. I Orig. 182:324-356.

19. Liebscher, S. 1964. Differenzierung von Bifidusbakterien aus Säuglings und Erwachsenenstuhl. Zentralbl. Bakteriol. Parasitenk. Infektionskr. Hyg. Abt. I Orig. 193:60-70.

20. McCarthy, B. J. 1967. Arrangement of base sequences in deoxyribonucleic acid. Bacteriol. Rev. 31:215--229.

21. McCarthy, B. J., and E. T. Bolton. 1963. An approach to the measurement of genetic relatedness among organisms. Proc. Nat. Acad. Sci. U.S.A. 50:156-164.

22. Malyoth, G., and A. Bauer. 1950. Beobachtungen am Bacterium bifidum. Z. Kinderheilk. 68:358-367.

23. Marmur, J. 1961. A procedure for the isolation of deoxyribonucleic acid from microorganisms. J. Mol. Biol. 3:208-218.

24. Marmur, J., and P. Doty. 1961. Thermal renaturation of deoxyribonucleic acids. J. Mol. Biol. 3:585-594

25. Marmur, J., and P. Doty. 1962. Determination of the base composition of deoxyribonucleic acid from its thermal denaturation temperature. $J$. Mol. Biol. 5:109-118.

26. Matteuzzi, D., F. Crociani, G. Zani, and L. D. Trovatelli. 1971. Bifidobacterium suis n.sp.: a new species of the genus Bifidobacterium isolated from pig feces. Z. Allg. Mikrobiol. 11:387-395.

27. Mitsuoka, T. 1969. Vergleichende Untersuchungen über die Bifidobakterien aus dem Verdauungstrakt von Menschen und Tieren. Zentralbl. Bakteriol. Parasitenk. Infektionskr. Hyg. Abt. I Orig. 210:52-64.

28. Mitsuoka, T., T. Sega, and S. Yamamoto. 1965. Eine verbesserte Methodik der qualitativen und quantitativen Analyse der Darmflora von Menschen und Tieren. Zentralbl. Bakteriol. Parasitenk. Infektionskr. Hyg. Abt. I Orig. 195:455-469.

29. Müller, H., and H. Pech. 1967. Bifidusbakterien bei der Frau. Arch. Gynäkol. 205:39-58.

30. Orla-Jensen, S. 1924. La classification des bactéries lactiques. Lait 4:468-474.

31. Orla-Jensen, S., A. D. Orla-Jensen, and O. Winter. 1936. Bacterium bifidum und Thermobacterium intestinale. Zentralbl. Bakteriol. Parasitenk. Infectionskr. Hyg. Abt. II 93: 321-343.

32. Petuely, F., and G. Lindner. 1965. Kritische 
Untersuchung über die Darmflora. III Mitt.: Bewertung quantitativer Züchtungsmethoden. Die Darmflora des Brustkindes. Zentralbl. Bakteriol. Parasitenk. Infektionskr. Hyg. Abt. I Orig. 195:347-384.

33. Pine, L. 1970. Classification and phylogenetic relationship of microaerophilic actinomycetes. Int. J. Syst. Bacteriol. 20:445-474.

34. Prévot, A. R. 1938. Etudes de systématique bactérienne. III. Invalidité du genre Bacteroides Castellani et Chalmers; démembrement et reclassification. Ann. Inst. Pasteur 60:285-307.

35. Prévot, A. R. 1970. Importance of the biochemical composition of the cell wall as a taxonomic characteristic. Int. J. Syst. Bacteriol. 20:539-540.

36. Reuter, G. 1963-64. Vergleichende Untersuchungen über die Bifidus-Flora im Sauglingsund Erwachsenenstuhl. Zentralbl. Bakteriol. Parasitenk. Infektionskr. Hyg. Abt. I Orig. 191:486-507.

37. Reuter, G. 1971. Designation of type strains for Bifidobacterium species. Int. J. Syst. Bacteriol. 21:273-275.

38. Scardovi, V., B. Sgorbati, and G. Zani. 1971. Starch gel electrophoresis of fructose-6-phosphate phosphoketolase in the genus Bifidobacterium. J. Bacteriol. 106:1036-1039.

39. Scardovi, V., and L. D. Trovatelli. 1965. The fructose-6-phosphate shunt as peculiar pattern of hexose degradation in the genus Bifidobacterium. Ann. Microbiol. 15:19-29.
40. Scardovi, V., and L. D. Trovatelli. 1969. New species of bifid bacteria from Apis mellifica $\mathrm{L}$. and Apis indica F. A contribution to the taxonomy and biochemistry of the genus Bifidobacterium. Zentralbl. Bakteriol. Parasitenk. Infektionskr. Hyg. Abt. II 123:64-88.

41. Scardovi, V., L. D. Trovatelli, F. Crociani, and B. Sgorbati. 1969. Bifid bacteria in bovine rumen. New species of the genus Bifidobacterium: $B$. globosum n. sp. and B. ruminale n. sp. Arch. Mikrobiol. 68:278-294.

42. Scardovi, V., G. Zani, and L. D. Trovatelli. 1970. Deoxyribonucleic acid homology among the species of the genus Bifidobacterium isolated from animals. Arch. Mikrobiol. 72:318-325.

43. Schramm, M., V. Klybas, and F. Racker. 1958. Phosphoroly tic cleavage of fructose-6-phosphate phosphoketolase from Acetobacter xylinum. J. Biol. Chem. 233:1283-1288.

44. Seeliger, H. P. R., and H. Werner. 1963. Recherches qualitatives et quantitatives sur la flore intestinale de l'homme. Ann. Inst. Pasteur 105:911-936.

45. Sgorbati, B., G. Zani, L. D. Trovatelli, and V. Scardovi. 1970. Gluconate dissimilation by the bifid bacteria of the honey bee. Ann. Microbiol. 20:57-64.

46. Werner, H., and H. P. R. Seeliger. 1963. Kulturelle Untersuchungen über die Vaginalflora unter besonderer Berücksichtigung der Bifidusbakterien. Pathol. Microbiol. 26:53-73. 